\title{
Bile salt inhibition of motility in the isolated perfused rabbit terminal ileum
}

\author{
D N Armstrong, H K Krenz, I M Modlin, G H Ballantyne
}

\begin{abstract}
The effects of bile on small bowel motility were studied in isolated, perfused rabbit terminal ileum. It was proposed that bile delivery into the distal ileum would inhibit ileal motor activity, by peptide YY (PYY) release and therefore the effect of luminal bile on motor activity was examined and PYY release measured. Luminal bile and taurocheodeoxycholic acid (10 mmol) inhibited ileal motor activity. Arterial infusion of venous effluents from a bile inhibited ileum suppressed motor activity in a second isolated ileum. This shows the presence of a humoral inhibitor of ileal motor activity. Luminal bile increased venous PYY concentrations $(42.5(8.5)$ to $502(46.2)$ $\mathrm{pmol} / \mathrm{l} ; \mathrm{p}<0.01)$ and increased bile salt values $(1.7(0.36)$ to $88.6(5.6) 10 \mu \mathrm{mol} / \mathrm{l} / \mathrm{l} ; \mathrm{p}<0.005)$. Arterial infusion of taurocheodeoxycholic acid at concentrations found in the venous effluent $(100 \mu \mathrm{mol} / \mathrm{l} / \mathrm{l})$ suppressed motility $(\mathbf{p}<\mathbf{0 . 0 0 1})$ but infusion of PYY at concentrations in the venous effluent $(500.0 \mathrm{pmol} / \mathrm{l})$ failed to inhibit motility. Furthermore, PYY antagonist, PYX 1 , failed to reverse the bile induced inhibition of motility. Luminal bile salts inhibit terminal ileal motility and this is independent of PYY release. By slowing motility, bile salts may participate in their own absorption by the 'ileal pump' and in the 'ileal brake' mechanism.

(Gut 1993; 34: 483-488)
\end{abstract}

Bile and bile salts inhibit motility and it has been proposed that they take part in the putative 'ileal brake' mechanism. It has been reported that gastric infusion of bile salts in rats delays gastric emptying and inhibits small bowel transit time. ${ }^{1}$ Similarly, infusion of bile salts into the jejunum or ileum of healthy volunteers slows small intestinal transit and inhibits intestinal myoelectrical activity. ${ }^{23}$ An analogous phenomenon has been noted in some diarrhoeal syndromes such as tropical sprue, coeliac disease, and short gut syndrome, where intestinal transit is reflexly inhibited. ${ }^{45}$ It has been proposed that the effector mechanism for this inhibition is located in the terminal ileum and is therefore often referred to as the 'ileal brake'. ${ }^{67}$

The ileal brake was initially defined by showing that the infusion of fat into the terminal ileum in man slowed both gastric emptying and intestinal transit. ${ }^{67}$ These studies provide circumstantial evidence that the 'ileal brake' reflex may be mediated by the release of peptide YY (PYY) from the terminal ileal mucosa. ${ }^{8} \mathrm{PYY}$ is found in high concentrations in the terminal ileum and is released after meals. In addition, infusion of PYY inhibits gastric emptying and prolongs the mouth to caecal transit time in man. ${ }^{9}$ This effect of PYY seems to be mediated by inhibition of cholinergic neurotransmission through a pertussis toxin sensitive mechanism. ${ }^{10}$ Little direct evidence exists; however, to support the initial proposal that PYY itself is the mediator of the 'ileal brake' reflex.

PYY and its close homologue, neurotransmitter neuropeptide Y (NPY) share sequence homology in the $\mathrm{C}$ terminal fragments, which are responsible for receptor binding and biological activity of the peptides. Both peptides have essentially identical biological activities. Study of the actions of PYY and NPY have been helped by the recent description of synthetic decapeptide amide antagonists, PYX 1 and PYX 2." PYX 1 is physiologically active in vitro at concentrations of $1 \cdot 0-10 \mu \mathrm{mol} / \mathrm{l} / \mathrm{l}$ and PYX 2 at $0 \cdot 1-1 \cdot 0 \mu \mathrm{mol} / \mathrm{l} / \mathrm{l}$. The specificity of these antagonists has been shown in vitro and they provide a valuable research tool with potential widespread clinical application.

We used a model of isolated, perfused rabbit terminal ileum to characterise the effects of luminal bile salts on intestinal motility. In addition, the role of gut peptides in mediating the actions of bile on ileal motility is investigated, and the relation of these mechanisms to the 'ileal brake' reflex is explored.

\section{Methods}

PREPARATION OF ISOLATED ILEUM

New Zealand white rabbits $(2 \mathrm{~kg})$ were anaesthetised using ketamine $\mathrm{HCl}(50 \mathrm{mg} / \mathrm{kg})$ and xyalazine $(20 \mathrm{mg} / \mathrm{kg})$. Intravenous fluid (Ringer's lactate) was given through a lateral ear vein at a rate which maintained stable vital signs. Heparin (2000 IU) was given intravenously at the beginning of the procedure. Through a midline laparotomy, the ileocolic artery and vein were cannulated using standard intravenous catheters (20G Cathlon, Critikon, Tampa, Florida, USA). The ileocolic artery was perfused immediately at $3 \mathrm{ml} / \mathrm{min}$ using warmed $\left(37^{\circ} \mathrm{C}\right)$, oxygenated $(95 \%$ $\mathrm{O}_{2}, \quad 5 \% \quad \mathrm{CO}_{2}$ ) Krebs-Ringer's bicarbonate solution $(\mathrm{NaCl} 118.4 \mathrm{mmol}, \mathrm{KCl} 4.7 \mathrm{mmol}$, $\mathrm{CaCl}_{2} 2.5 \mathrm{mmol}, \mathrm{MgCl}_{2} 1.3 \mathrm{mmol}, \mathrm{NaHCO}_{3}$ $23.4 \mathrm{mmol}, \mathrm{NaH}_{2} \mathrm{PO}_{4} 0.12 \mathrm{mmol}$, dextrose $5.6 \mathrm{mmol}$, bovine serum albumin $30 \mu \mathrm{mol}$ ). A $10 \mathrm{~cm}$ length of terminal ileum based on the ileocolic artery was isolated and peripheral vascular branches were ligated and divided to avoid loss of perfusate. At the end of the operation, the animal was killed with additional ketamine $(200 \mathrm{mg} / \mathrm{kg}$ iv $)$ followed by a saturated $\mathrm{KCl}$ solution $(5 \mathrm{ml}$ iv).

The isolated ileum was transferred to a humidified organ plate and maintained at $37^{\circ} \mathrm{C}$. Arterial perfusate was infused by roller pump 
from a warmed fluid oxygenator. The venous effluent was collected from the cannulated ileocolic vein with a fraction collector. The perfusate passed in a single cycle through the organ and was not recirculated. To ensure viability of the organs, $\mathrm{pH}, \mathrm{PO}_{2}$, and $\mathrm{PCO}_{2}$ of both the arterial infusate and venous effluent were measured every hour throughout the experiments.

\section{MEASUREMENT OF ILEAL MOTILITY}

Motility of the ileal segment was measured by inserting a multilumen manometry catheter into the proximal end of the ileal segment. The manometer ports were spaced every $2.5 \mathrm{~cm}$ and perfused at a constant pressure of $15 \mathrm{~cm} \mathrm{H}_{2} \mathrm{O}$ with distilled water (a total volume $0.3 \mathrm{ml} / \mathrm{min}$ ) (JS Biomedicals, Ventura, California, USA). Depending on the length of ileum used, three or four manometer channels were used to record motility. The manometer catheter was linked to pressure transducers which were interfaced to a polygraph (Narco Biosystems MMS 200, Houston, Texas, USA). The analogue signal was stored in digitised form on a computer hard drive (PC System 2 Model 70, 386, IBM, Armonk, New York, USA). The cholinergic agonist carbachol was infused intra-arterially at a final concentration of $0 \cdot 1 \mu \mathrm{mol} / 1$ to maintain consistent motor activity. This was continued throughout the experiment. Ileal motility was measured by integrating the area under the pressure-time curve, during 1 minute periods, using computer software (Narco MMS, Houston, Texas, USA). The mean activity in all channels was used to quantitate motility and was expressed in units of $\mathrm{mm} \mathrm{Hg} / \mathrm{min}$.

Vasoactive intestinal peptide (VIP) concentrations were measured by radioimmunoassay. ${ }^{12}$ Antisera to pure porcine VIP were produced in rabbits by multiple subcutaneous injections of VIP (100 nmol/rabbit), conjugated to $50 \mathrm{nmol} / 1$ bovine serum albumin (BSA) by carbodiimide condensation, emulsified in complete Freud's adjuvant 23. Incorporation of $0 \cdot 7-1 \cdot 1 \mathrm{nmol} / 1{ }^{125} \mathrm{I}$ IMS 30 (Amersham) (approximately $2 \mathrm{mCi} / \mathrm{mol}$ ) into $6 \mathrm{nmol} / \mathrm{l}$ pure porcine VIP in $50 \mathrm{mmol} / \mathrm{l}$ acetate buffer at $\mathrm{pH} 5.0$ was achieved by incubating with $22 \mathrm{pmol} / \mathrm{l}$ lactoperoxidase and 1.8 $\mathrm{nmol} / 1 \mathrm{H}_{2} \mathrm{O}_{2}$ at room temperature for 15 minutes in a total volume of $130 \mu \mathrm{l}$. The iodinated VIP was purified using high resolution, reverse phase, high pressure liquid chromatography.

Concentrations of PYY were measured using a well characterised radioimmunoassay which we have described in detail elsewhere. ${ }^{13}$ The antibody (Y 21) was raised in a rabbit immunised with unconjugated pure PYY. Synthetic PYY was iodinated by conventional chloramine $T$ oxidation and labelled PYY purified using high resolution, reverse phase, high pressure liquid chromatography. This assay detects changes between adjacent tubes of $0 \cdot 4 / 1$ (equivalent to $4 \mathrm{pmol} / \mathrm{l}$ perfusate) with $95 \%$ confidence. The dose of PYY required to reduce binding of $1 \mathrm{fmol} / 1$ labelled PYY by $50 \%$ was $9 /$ tube. The antiserum is directed to the $\mathrm{N}$ terminal. There is no significant cross reaction of this assay with the related peptides NPY or pancreatic polypeptide (PP).

Enteroglucagon was measured by an assay system. ${ }^{12}$ Enteroglucagon was measured utilising an antibody (GL 77) that fully recognises pancreatic glucagon and enteroglucagon, the antibody being directed to the $\mathrm{N}$ terminal. Because there were no potential sources of pancreatic glucagon in isolated perfused segments of terminal ileum, enteroglucagon concentrations were measured directly with antibody GL 77 in this preparation. Subtraction techniques which are required when measuring enteroglucagon in plasma were not needed. The assay shows no significant cross reaction with related peptides (secretin, VIP, PHI, GRF, and GIP) and detects changes of $0 \cdot 2 /$ tube with $95 \%$ confidence (equivalent to $3 \mathrm{pmol} / \mathrm{l}$ enteroglucagon/l perfusate) (GL77). In both human and porcine ileal extracts, the antibody (GL77) recognises a peak in the gel permeation chromatograms which elutes in the position of oxyntomodulin. Neither GLP 1 nor GLP 2 are detected.

Total bile salts in the venous effluent were measured using direct spectofluorometry (Sterognost 3a Flu, Nyegaard Diagnostica, Oslo, Norway).

\section{EXPERIMENTAL DESIGN}

Baseline ileal motility was measured after equilibration and during carbachol $(0 \div 1 \mu \mathrm{mol} / \mathrm{l})$ infusion. Examination of the effects of bile and bile salts were performed in five stages.

\section{Experiment 1: effect of intraluminal bile and} taurodeoxycholic acid on ileal motility Bile $(0.5 \mathrm{ml})$ was taken from the gall bladder at laparotomy and infused into the proximal ileum over a two minute period. Motility was measured in response to luminal bile and after washout of the lumen. These experiments were repeated using taurodeoxycholic acid (0.1-10 $\mathrm{mmol} / \mathrm{l})$.

\section{Experiment 2: intra-arterial infusion of venous effluents}

During carbachol infusion and bile stimulation (Experiment 1), the venous effluents were collected and reinfused into an isolated segment from a second rabbit at $0.3 \mathrm{ml} / \mathrm{min}$, at a rate of one tenth the total perfusion rate to prevent hypoxia. Infusion time for the effluents was two minutes. Motility was recorded during infusion of each set of effluents. This allowed the identification of a humoral mediator which might be responsible for the motility changes.

Experiment 3: bile stimulated release of PYY, $V I P$, and total bile salts in venous effluent

During each of the stages described above, $15 \mathrm{ml}$ of effluent from the venous catheter was collected for five minutes after the start of infusion. This was frozen at $-20^{\circ} \mathrm{C}$ for subsequent determination of PYY, VIP, and bile salt concentrations. 
Experiment 4: motor activity in response to intraarterial infusion of $P Y Y$ and taurodeoxycholic acid (TDCA)

To find out if PYY or bile salts were responsible

TABLE Arterial and venous $p H, \mathrm{PO}_{2}$, and $\mathrm{HCO}_{3}^{-}$values in isolated perfused segments of rabbit terminal ileum. All values remained within physiological limits during the three hours of perfusion

\begin{tabular}{|c|c|c|c|c|c|c|}
\hline \multirow[b]{2}{*}{ Time } & \multicolumn{3}{|l|}{ Arterial } & \multicolumn{3}{|l|}{ Venous } \\
\hline & $p H$ & $\mathrm{PO}_{2}$ & $\mathrm{HCO}_{3}^{-}$ & $p H$ & $\mathrm{PO}_{2}$ & $\mathrm{HCO}_{3}^{-}$ \\
\hline $\begin{array}{l}30 \mathrm{~min} \\
1 \mathrm{~h} \\
2 \mathrm{~h} \\
3 \mathrm{~h}\end{array}$ & $\begin{array}{l}7.47(0.02) \\
7.47(0.02) \\
7.44(0.03) \\
7.43(0.02)\end{array}$ & $\begin{array}{l}271(15) \\
260(18) \\
192(17) \\
256(29)\end{array}$ & $\begin{array}{l}18 \cdot 5(1 \cdot 0) \\
20 \cdot 0(1 \cdot 5) \\
17 \cdot 8(2 \cdot 0) \\
18 \cdot 0(2 \cdot 1)\end{array}$ & $\begin{array}{l}7.46(0.02) \\
7.41(0.02) \\
7.41(0.03) \\
7.45(0.03)\end{array}$ & $\begin{array}{c}137(7) \\
129(10) \\
87(13) \\
112(16)\end{array}$ & $\begin{array}{l}20.1(1.0) \\
21.7(1.0) \\
20.6(2.4) \\
21.4(2.1)\end{array}$ \\
\hline
\end{tabular}
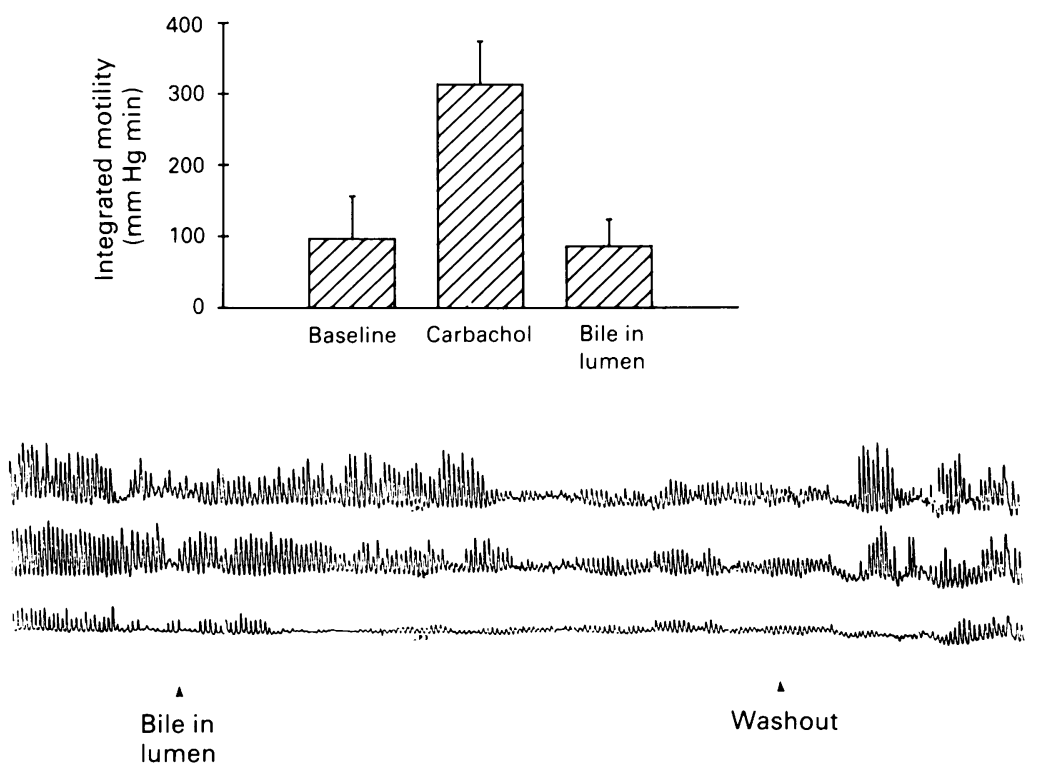

Figure 1: Infusion of carbachol $(0 \cdot 1 \mu \mathrm{mol} / \mathrm{l})$ into the arterial system of isolated, perfused segments of rabbit terminal ileum, stimulated motor activity. Motor activity was inhibited by luminal infusion of bile and returned to pre-inhibition values after washout of bile. Above: Motility is quantitated by integration of the area under the motility tracings curve(integrated motility) and is expressed in units of $\mathrm{mm} \mathrm{Hg} / \mathrm{min}$. Motility is stimulated by carbachol and inhibited by infusion of bile into the intestinal lumen.

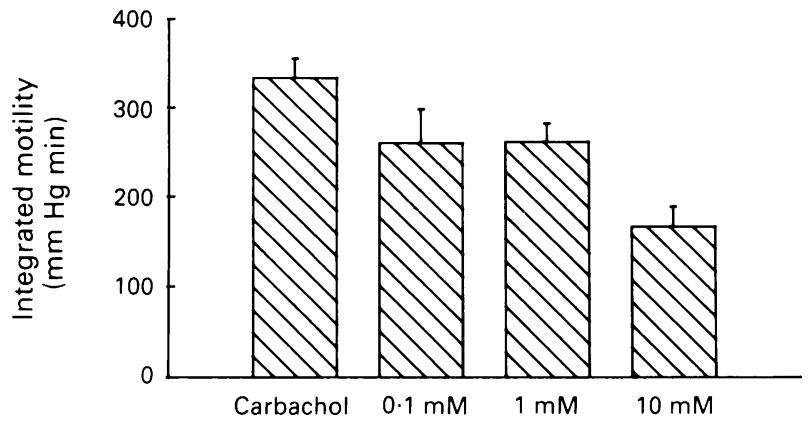

Taurocheodeoxycholic acid (TDCA)

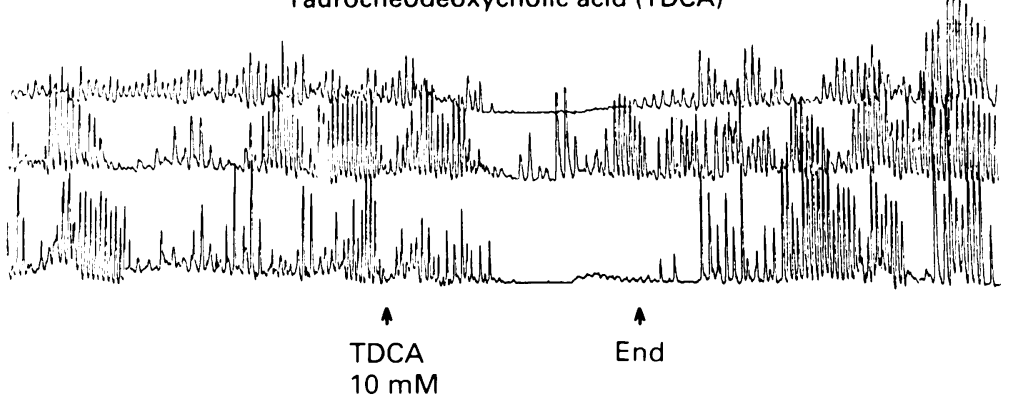

Figure 2: Luminal infusion of TDCA $(10 \mathrm{mmol} / \mathrm{l})$ significantly $(p<0.01)$ inhibited carbachol $(0 \cdot 1 \mu \mathrm{mol} / \mathrm{l})$ stimulated motor activity. Motor activity returned to stimulated values after washout of the lumen. Duration of TDCA infusion is two minutes. Above: Intraluminal infusion of TDCA $(10 \mathrm{mmol} / \mathrm{l})$ significantly inhibited carbachol stimulated integrated motor activity, but did not do so at concentrations of 1 , or $0.1 \mathrm{mmol} / \mathrm{l}$. for the inhibition of motility, each was separately infused intra-arterially over a two minute period, at the concentrations found in the venous effluents. Motility was again recorded. PYY values were measured in the venous effluents collected before and during arterial infusion of TDCA

Experiment 5: effect of intra-arterial infusion of $P Y X 1$ on bile inhibition of ileal motility

Bile infusion in experiment 3 caused a release of PYY. Since PYY inhibits ileal motility, we tested the effect of PYX 1 which is a specific antagonist of NPY and PYY. In each study, continuous infusion of intra-arterial PYX $(0 \cdot 1-1 \cdot 0 \mu \mathrm{mol} / \mathrm{l})$ was started five minutes after the start of the carbachol $(0 \cdot 1 \mu \mathrm{mol} / \mathrm{l})$ infusion and stopped five minutes before the end of the carbachol infusion. Intraluminal infusion of bile $(0.5 \mathrm{ml})$ was started five minutes after initiation of the PYX 1 infusion. Each study lasted a total of 25 minutes.

\section{STATISTICS}

Motility was quantified by integrating area under the pressure tracings curve in four manometer channels. For each experiment, the mean of all four channels was derived and expressed in units of $\mathrm{mm} \mathrm{Hg} / \mathrm{min}$. Bile salt and peptides were measured in molar concentrations. Values of significance were derived from independent $t$ test.

\section{Results}

\section{ORGAN VIABILITY}

The table summarises the $\mathrm{pH}, \mathrm{PO}_{2}$, and $\mathrm{HCO}_{3}$ of the arterial perfusate during the course of the experiments. Satisfactory oxygenation was obtained in all experiments and the $\mathrm{PO}_{2}$ in the venous effluents remained $>90 \mathrm{~mm} \mathrm{Hg}$.

Experiment 1: effect of intraluminal bile $(n=5)$ and TDCA $(n=5)$ on ileal motility

After a 30 minute recovery period following harvest of the ileal segment, basal motor activity was $96(59) \mathrm{mm} \mathrm{Hg} / \mathrm{min}$ (Fig 1). Carbachol (0.1 $\mu \mathrm{mol} / \mathrm{l})$ infusion produced a significant $(\mathrm{p}<0.01)$ threefold increase in motor activity; $306(74) \mathrm{mm} \mathrm{Hg} / \mathrm{min}$. Bile obtained by aspiration from the gall bladders of anaesthetised rabbits contained bile acids in a concentration of 8.8 $(2 \cdot 3) \mathrm{mmol} / \mathrm{l}$. Figure 1 shows the effect of infusion of rabbit bile into the ileal lumen on carbachol stimulated motor activity. The amplitude of the pressure waves declined after a latency period of about 2 to 3 minutes. The frequency of the pressure waves remained unchanged. Motor activity decreased to baseline values; 78 (45) $\mathrm{mm} \mathrm{Hg} / \mathrm{min}$. After washout of the bile, the amplitude of the pressure waves increased to previous values; $327(86) \mathrm{mm} \mathrm{Hg}$ / min. Figure 1 summarises motor activity at all stages of the experiments. Infusion of TDCA at $10 \mathrm{mmol} / \mathrm{l}$ but not at $1 \mathrm{mmol} / \mathrm{l}$ into the ileal lumen produced a significant $(\mathrm{p}<0.01)$ inhibition of motor activity (Fig 2). The frequency remained unchanged. Thus, luminal infusion of rabbit bile 


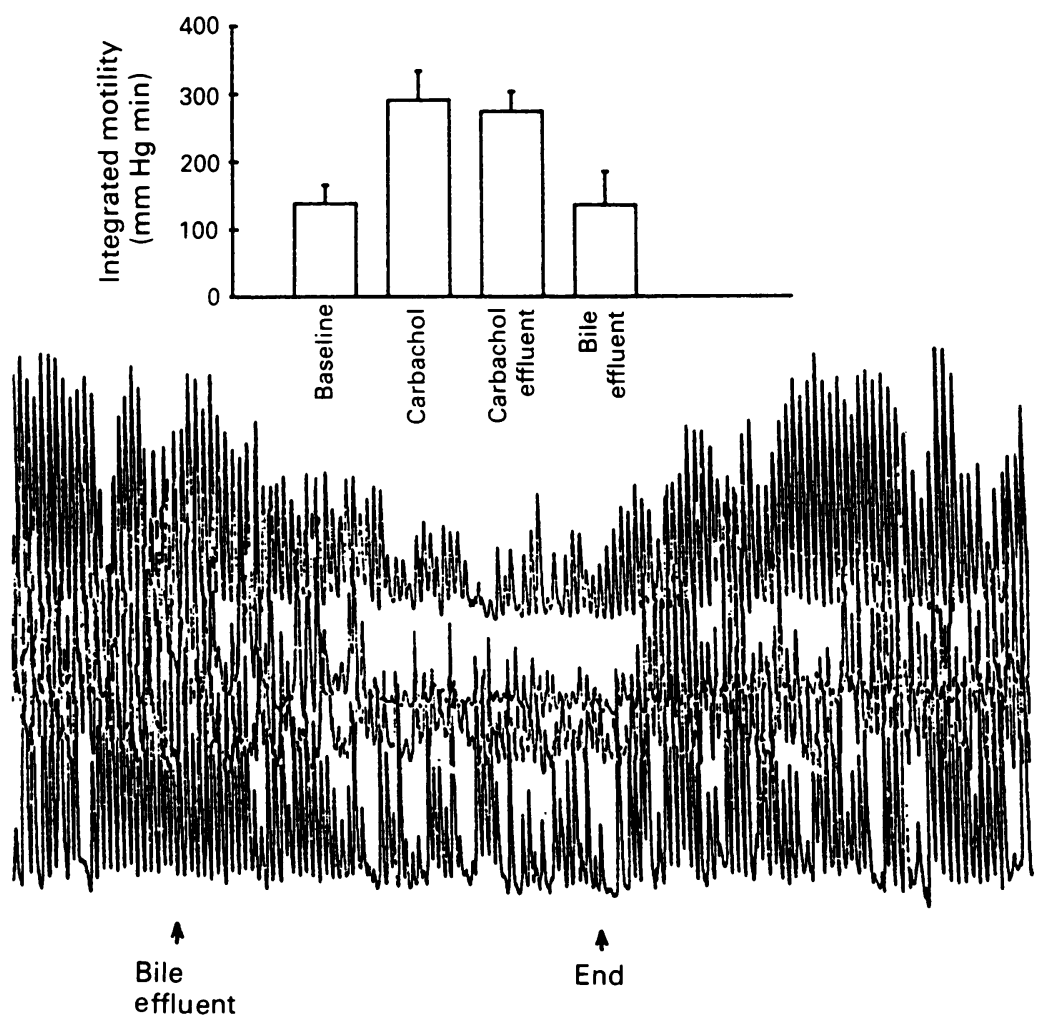

Figure 3: Arterial infusion of oxygenated venous effluents, collected during luminal infusion of bile in ileal segments, decreased motor activity to near basal values when infused into a second ileal segment. Duration of infusion is two minutes. The inhibition was reversible,

after stopping infusion of the effluent. Above: Basal and carbachol $(0 \cdot 1 \mu \mathrm{mol} / \mathrm{l})$ stimulated motor activity in isolated ileal segments (first two columns). Venous effluents, collected from an isolated ileum segment, did not inhibit motility in a second isolated segment (third column). Venous effluents collected during luminal infusion of bile significantly $(p<0.01)$ inhibited motor activity in a second segment of ileum (fourth column) and TDCA inhibited motor activity in isolated segments of rabbit terminal ileum.

\section{Experiment 2: intra-arterial infusion of venous effluents $(n=4)$}

Arterial infusion of venous effluents collected before bile stimulation did not change motor activity. Venous effluents collected during infusion of bile, however, did significantly $(\mathrm{p}<0.01)$ inhibit ileal motility after a very short latency (Fig 3). This inhibition was reversible and motility returned to previous values after the infusion was stopped. Figure 3 summarises motor activity before, during, and after infusion of venous effluents. These studies showed that a humoral agent present in the venous effluent during luminal administration of bile, inhibited motor activity in isolated segments of terminal ileum.

Experiment 3: bile stimulated release of $P Y Y$, enteroglucagon, VIP, and total bile acids in venous effluenct $(n=5)$

Figure 4 shows the basal values of PYY, enteroglucagon, and VIP. Intra-arterial infusion of carbachol $(0 \cdot 1 \mu \mathrm{mol} / \mathrm{l})$ caused a small but significant $(p<0.05)$ increase in PYY concentrations in the venous effluent from $29 \cdot 8(8 \cdot 7) \mathrm{pmol} / \mathrm{l}$ to 125 (20) pmol/l. PYY values significantly $(\mathrm{p}<0 \cdot 01)$ increased to $428(69) \mathrm{pmol} / \mathrm{l}$ during intraluminal infusion of bile. Neither intra-arterial infusion of carbachol $(0 \cdot 1 \mu \mathrm{mol} / \mathrm{l})$ nor intraluminal infusion of bile significantly changed venous effluent concentrations of enteroglucagon or VIP. Therefore, luminal infusion of bile significantly increased the release of PYY but not of enteroglucagon or VIP. Figure 5 shows total bile acid values in the venous effluent during basal (unstimulated) periods, intra-arterial infusion of

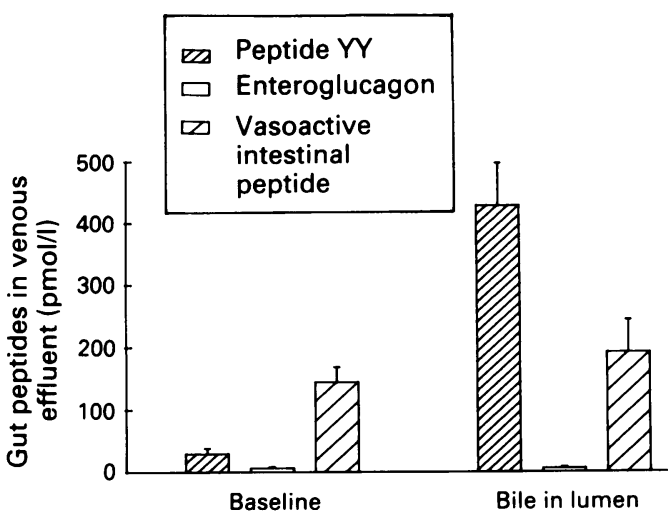

Figure 4. Values of PYY, enteroglucagon, and VIP in the venous effluent of isolated segments of terminal ileum before (baseline) and during luminal infusion of bile. PYY concentrations in the venous perfusate increased more than 10 fold during bile infusion, while enteroglucagon and VIP values remained unchanged.

carbachol $(0.1 \mu \mathrm{mol} / \mathrm{l})$, and intraluminal infusion of bile. The total bile acid concentration in the venous effluent significantly $(p<0.01)$ increased from mean (SD) basal values of 1.7 $(0.36) \mu \mathrm{mol} / \mathrm{l}$ to $88.6(5.6) \mu \mathrm{mol} / 1$ during luminal infusion of bile. Thus, luminal infusion of bile caused a 50 fold increase in venous effluent concentrations of bile acids.

Experiment 4: changes in motor activity in response to intra-arterial infusion of $P Y Y(n=7)$ and TDCA $(n=4)$

Intra-arterial infusion of PYY $(0 \cdot 1 \mu \mathrm{mol} / \mathrm{l})$ significantly $(\mathrm{p}<0.01)$ inhibited carbachol $(0 \cdot 1$ $\mu \mathrm{mol} / \mathrm{l}$ ) stimulated motor activity (Fig 6). Lower concentrations of PYY $(10 \mathrm{pmol} / 1-10 \mathrm{nmol} / \mathrm{l}) \mathrm{did}$ not significantly $(p>0.05)$ inhibit carbachol stimulated motor activity (Fig 6 Top). Intraarterial infusion of TCDA $(1-100 \mu \mathrm{mol} / \mathrm{l})$ inhibited motility in a concentration dependant manner (Fig 7) and this inhibition was reversible, after stopping the infusion. Although arterial infusion of TDCA $(100 \mu \mathrm{mol} / \mathrm{l})$ significantly inhibited motor activity, it failed to stimulate the release of PYY (67 (10) pmol/1 $v 93$ (22) $\mathrm{pmol} / \mathrm{l} ; \mathrm{p}>0.05, \mathrm{n}=5)$. Thus TDCA, but not PYY, at concentrations similar to those seen in the venous effluent of experiment 3 inhibited motor activity in isolated segments of terminal ileum.

Experiment 5: effect of intra-arterial infusion of $P Y X$ on bile inhibition of ileal motility $(n=3)$ Intra-arterial infusion of PYX $(0 \cdot 1-1 \cdot 0 \mu \mathrm{mol} / \mathrm{l})$

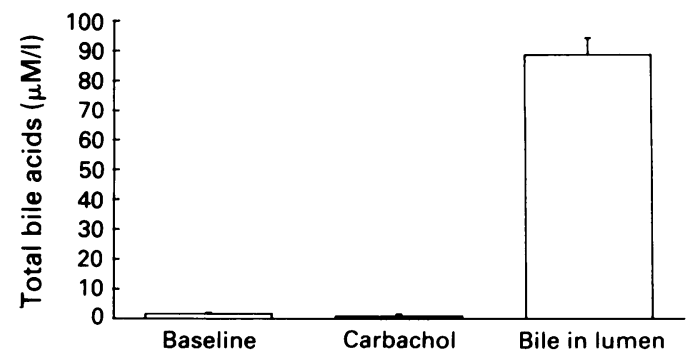

Figure 5: Intra-arterial infusion of carbachol $(0.01 \mathrm{umol} / \mathrm{l})$ did not change bile acid values $(p>0 \cdot 05)$. Total bile salt concentration in the venous effluents increased more than 50 fold during infusion of bile into the ileal lumen $(p<0 \cdot 01)$. 


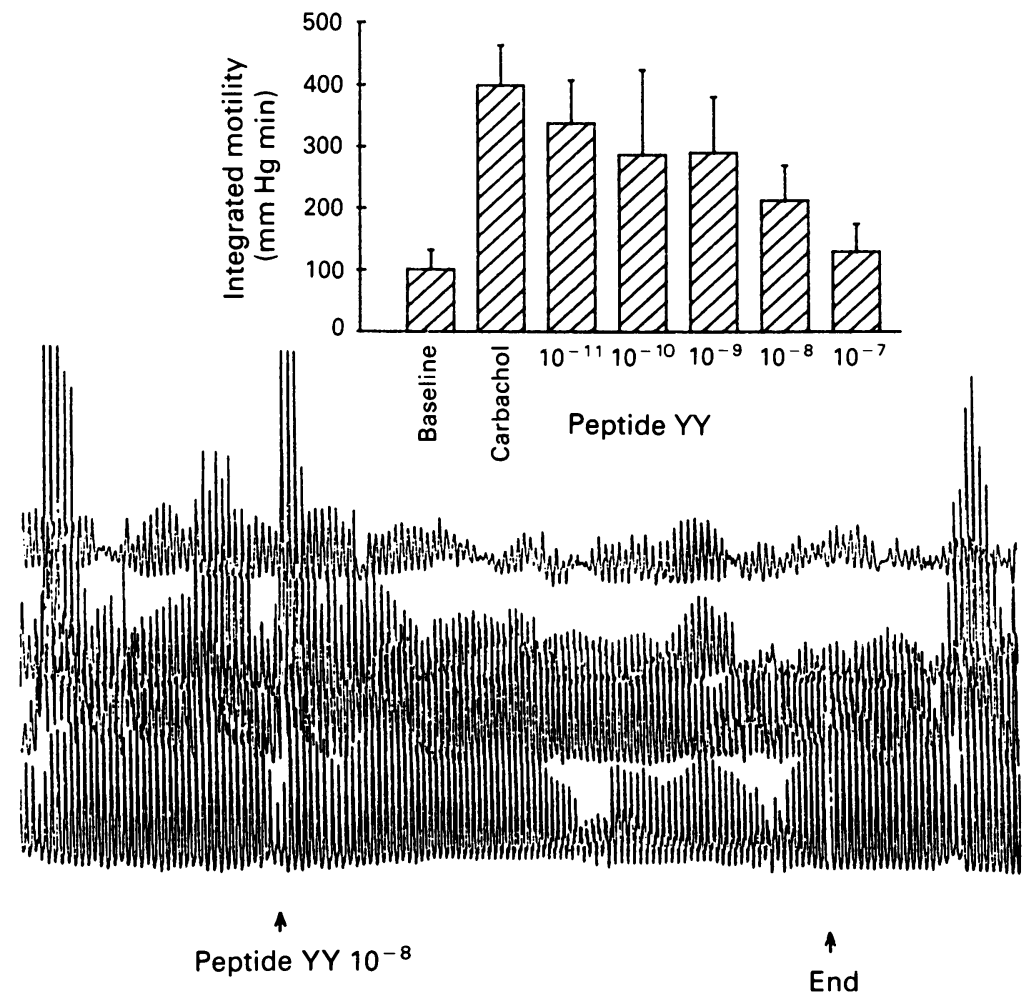

Figure 6: Intra-arterial infusion of $P Y Y(0 \cdot 1$ umolll) significantly inhibited carbachol $(0 \cdot 1$ $\mu \mathrm{m} / \mathrm{l})$ stimulated motor activity in isolated ileal segments. Above: Concentrations of $P Y Y$ (from 10 pmolll to 10 nmolll) did not significantly inhibit carbachol stimulated motor activity.

did not significantly ( $p>0.05)$ change carbachol stimulated ileal motor activity. Similarly, infusion of PYX did not prevent bile inhibition of ileal motor activity.

\section{Discussion}

This study showed that luminal infusion of bile
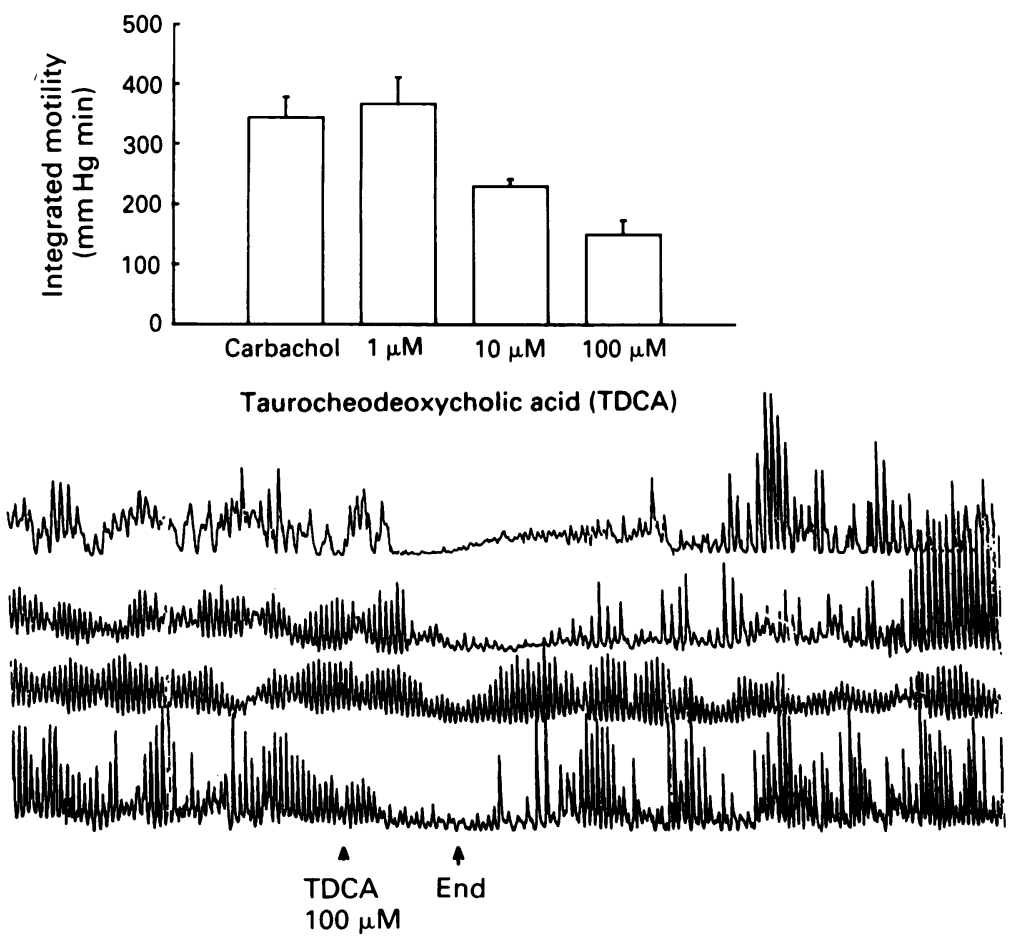

Figure 7: Arterial infusion of taurodeoxycholic acid (TCDA; $100 \mu \mathrm{mol} / \mathrm{l})$ significantly $(p<0 \cdot 01)$ inhibitd carbachol $(0.1 \mu \mathrm{mol} / \mathrm{l})$ stimulated motor activity in isolated ileal segments. Latency was less than one minute and the effect was reversible after stopping the infusion.

Duration of infusion is one minute. Above: Intra-arterial infusion of TDCA at concentrations of 10 and 100 mol/l significantly inhibited carbachol stimulated motor activity, but did not do so at a concentration of $1 \mu \mathrm{mol} / \mathrm{l}$. and the bile acid TDCA inhibited carbachol stimulated motor activity in isolated segments of rabbit terminal ileum. This inhibition was reproduced in a second isolated segment of terminal ileum by arterial infusion of the venous effluent collected from terminal ileums that had been luminally perfused with bile. This suggested that bile inhibition of ileal motor activity was mediated by a humoral agent from the terminal ileum present in the venous effluent. Indeed, PYY and bile salt concentrations in the venous effluents increased during luminal bile infusion, though enteroglucagon and VIP concentrations did not. When PYY was arterially infused at the concentrations seen in the venous effluents, no inhibition of motility occurred. In contrast, infusion of TDCA at these concentrations inhibited ileal motor activity. Thus, the bile itself seemed to be the inhibitory agent in the venous effluent. Furthermore, perfusion of the PYY receptor antagonist PYX 1 beforehand did not block the effect of bile infusion on ileal motility. These results indicated that bile and TDCA inhibited terminal ileal motor activity by a mechanism that was not mediated by PYY, enteroglucagon, or VIP. These findings suggested that bile and TDCA directly inhibited ileal motor activity.

Studies in rats have shown that bile salts inhibit gastric emptying and prolongs intestinal transit time. ${ }^{1}$ In man, infusion of bile salts into the jejunum at physiological concentrations prolongs small bowel transit time and inhibits intestinal motor activity. Fasting concentrations of bile salts in the upper small bowel have been measured at 3-4 mmol/1; the major component of the bile salts being conjugated to taurine or glycine. ${ }^{14}$ Postprandial concentrations reach $5 \mathrm{mmol} / \mathrm{l}$ in the jejunum and $10 \mathrm{mmol} / \mathrm{l}$ in the ileum. ${ }^{13}$ is In this model, we infused bile salts into the ileal lumen at a concentration of $10 \mathrm{mmol} / \mathrm{l}$, a level which both approximated these postprandial luminal values and significantly inhibited ileal motor activity. These findings suggest that postprandial increases in bile salt concentrations in the terminal ileum may play a role in the inhibition of ileal motility. This mechanism might facilitate bile salt absorption into the enterohepatic circulation by slowing intestinal transit time.

Bile salts are absorbed passively, to some extent, throughout the small intestine. Active reabsorption, however, is limited to the ileum (the 'ileal pump') and is accomplished by a specific active biological pump. ${ }^{16} 17$ In man portal venous bile salt concentrations increase from $22.2 \mu \mathrm{mol} / \mathrm{l}$ during fasting to $170 \mu \mathrm{mol} / \mathrm{l}$ after meals. In this study, a similar change in portal venous concentration of bile acids was seen; from basal values of $1.7(0.36)$ to $88.6(5.6) \mu \mathrm{mol} / \mathrm{l}$ during luminal infusion of bile (Fig 1). Infusion of venous effluents at a 1:10 dilution (bile salt content $8.8 \mu \mathrm{mol} / \mathrm{l}$ ) inhibited motor activity. This is consistent with the presence of a humoral mediator. Moreover, TDCA (10.0 $\mu \mathrm{mol} / \mathrm{l}$ ) produced a similar inhibition. It is therefore not unreasonable to propose that bile salts might be the inhibitory component in the venous effluent. 
As bile salts release PYY and PYY has been reported to slow intestinal transit time, it seemed possible that this peptide plays a role in the regulation of ileal motility. We therefore suggested that PYY might mediate the bile inhibition of ileal motility. Indeed, luminal bile did release PYY from the ileal mucosa. Reinfusion of PYY at concentrations seen in the venous effluent, however, failed to inhibit motility. Furthermore, preinfusion of PYX, a specific competitive antagonist of PYY, did not reduce bile inhibition of ileal motor activity. Thus, PYY does not seem to mediate the inhibition of ileal motility by bile. Nevertheless, infusion of PYY at much higher concentrations (two orders of magnitude higher) did produce inhibition of motility. Consequently, these results do not exclude a role for PYY in the mediation of the ileal brake mechanism. Indeed, previous in vivo studies have shown that intravenous administration of PYY in man at plasma concentrations seen postprandially inhibits gastric emptying and intestinal transit. ${ }^{9}$ It is therefore possible that PYY's ability to inhibit motility in whole animal and human models is a result of its action at a more proximal level in the gut or at a central location. If this is the case, such a reflex would not be reproducible in the present isolated model. Alternatively, PYY may cause the release of other inhibitory agents which are responsible for inhibiting motility. This is unlikely as the specific antagonist PYX 1 failed to reverse bile mediated inhibition. Our studies suggest that the arrival of bile salts in the ileum may be one of the factors that stimulate the postprandial release of PYY, although the peptide does not seem to inhibit motility locally.

Other regulatory peptides in the terminal ileum may mediate bile inhibition of ileal mctility. VIP is localised to neurones in the lamina propria, submucousal, and myenteric plexuses of the gut and mediates the descending inhibitory reflex. ${ }^{18}{ }^{19}$ VIP is released in dogs in response to such stimuli as gastric juice, vagal stimulation, and ileal bile. ${ }^{20}$ In our study, however, no release of VIP was seen in response to luminal infusion of bile. This inconsistency may reflect species differences. The absence of any detectable increase in VIP concentrations in our study suggested that this peptide did not play a significant part in the mediation of bile inhibition of ileal motility.

The manometry tracings of spontaneous ileal motility seen in this study closely resembled the in vivo patterns of small bowel motility described by other authors. ${ }^{2122}$ After 20-30 minutes of perfusion with oxygenated Krebs Ringer's bicarbonate solution, however, the amplitude of the pressure waves progressively declined. Intermittent periods of activity were seen thereafter but the timing, amplitude, and duration of this activity was unpredictable. Because acetylcholine is the endogenous agonist in mammalian small bowel in vivo, ${ }^{23}$ its cholinesterase resistant equivalent, carbachol, was used to mimic in vivo conditions. The motility patterns produced during intra-arterial infusion of carbachol $(0 \cdot 1$ $\mu \mathrm{mol} / \mathrm{l}$ ) were indistinguishable from those initially seen after harvest of the organ and those described in other mammals including man. ${ }^{22+}$
The requirement for exogenous administration of cholinergic agents to stimulate motility in isolated models of mammalian small bowel, has been described previously. ${ }^{23}$

This study has shown that luminal bile directly inhibited terminal ileal motility. It is possible that this effect on ileal motor activity may facilitate absorption of bile salts in the ileum by the 'ileal pump' mechanism by slowing intestinal transit time. These findings therefore suggest that bile salts may play a part in the mediation of the 'ileal brake' mechanism and that the 'ileal brake' may be mediated by several factors which may include bile salts and regulatory peptides such as PYY.

1 Feldman S, Gibaldi M. Effect of bile salts on gastric emptying and intestinal transit in the rat. Gastroenterology 1968;54: 918-21.

2 Penagini R, Misiewicz JJ, Frost PG. Effect of jejunal infusion of bile acids on small bowel transit and fasting jejunal of bility in man. Gut 1988;29: 789-94.

3 Penagini R, Spiller RC, Misiewicz JJ, Frost PG. Effect of ileal infusion of glycochenodeoxycholic acid on segmental infusion of glycochenodeoxycholic acid on segmenta transit, motility, and fil 1989; 30: 609-17.

4 Adrian TE, Ferri GL, Bacarese-Hamilton AJ, Feussel HS, Polak JM, Blook SR. Human distribution and release of a putative new hormone, peptide YY. Gastroenterology 1985 89: $1070-7$.

5 Adrian TE, Savage AP, Bacarese-Hamilton AJ, Wolfe K, Besterman HS, Bloom SR. Peptide YY adnormalities in gastrointestinal diseases. Gastroenterology 1986; 90: 379-84.

6 Macfarlane A, Kinsman R, Read NW, Bloom SR. The ilea brake: ileal fat slows down small bowel transit and gastric emptying in man. Gut 1983; 24: A472.

7 Spiller RC, Trotman IF, Higgins BE, Ghatei MA, Grimble GK, Lee YC, et al. The ileal brake - inhibition of jejunal motility after ileal fat perfusion in man. Gut 1984; 25: 365 74.

8 Pappas TN, Chang AM, Debas HT, Taylor IL. Does peptide YY (PYY) mediate the ileal brake? Gastroenterology 1985; 88 1529 [Abstract]

9 Savage AP, Adrian TE, Carolan G, Chatterjee V, Bloom SR Effect of peptide YY (PYY) on mouth to caecum intestina transit time and on the rate of gastric emptying in health volunteers. Gut 1987; 28: 166-70.

10 Wiley JW, Yuanxu L, Owyang C. Mechanism of action of peptide YY to inhibit gastric motility. Gastroenterology 1991; 100: $865-72$.

11 Tatemoto K. Neuropeptide $\mathrm{Y}$ and its receptor antagonists. Ann NY Acad Sci 1990; 611: 1-6.

12 Domschke S, Domschke W, Bloom SR. Vasoactive intestinal peptide in man. Pharmacokinetics, metabolic and peptide in man. Pharmacokinetics,

13 Ballantyne GH, Longo WE, Savoca PE, Adrian TE, Vukasin AP, Bilchik AJ, et al. Doxycholate stimulated release of peptide YY from the isolated perfused rabbit left colon. Am 7 Physiol 1989; 257 (Gastrointest Liver Physiol 20): G715-24.

14 Northfield TC, McColl I. Postprandial concentrations of free and conjugated bile acids down the length of the normal human small intestine. Gut 1973; 14: 513-8.

15 Carey MC, Cahalane MJ. Enterohepatic circulation, Chapter 33. In: Arias IM, ed. The liver, biology and pathobiology. 2nd ed. New York: Raven Press, 1988: 573-616.

16 Dietschy JM. Mechanisms for the intestinal absorption of bile salts. F Lipid Res 1968; 9: 297-309.

17 Sjovall J, Akesson I. Intestinal absorption of taurocholic acid in the rat. Acta Physiol Scand 1955; 34: 273-8.

18 Chijiiwa Y, Misawa T, Ibayashi H. Evidence of local mechanism involvement in vasoactive intestinal peptide release from canine small intestine. Gastroenterology 1986; 90: 1877 81

19 Grider JR, Makhlouf GM. Vasoactive intestinal peptide: transmitter of inhibitory motor neurones of the gut. Ann NY Acad Sci 1988; 527: 369-77.

20 Korman LY, Sayadi H, Bass B, Moody TW, Harmon JW Distribution of vasoactive intestinal peptide and substance receptors in human colon and small bowel. Dig Dis $S_{c i} 1989$ 34: 1100-8.

21 Putman WS, Liddle RA, Williams JA. Inhibitory regulation of rat exocrine pancreas by peptide YY and pancreatic polypeptide. Am F Physiol 1989; 256 (Gastrointest Liver Physiol 19): G698-703.

22 Sarna SK, Soergel KH, Harig JM, Loo FD, Wood CM, Donahue KM, et al Spatial and temporal patterns of human jejunal contractions. Am $\mathcal{F}$ Physiol 1989; 257 (Gastrointest

23 Fox JE, Daniel EE, Jury J, Robotham H. Muscarinic inhibi tion of canine small intestinal motility in vivo. Am $\mathcal{f}$ Physiol 1985; 248 (Gastrointest Liver Physiol 11): G526-31.

24 Summers RW, Anuras S, Green J. Jejunal manometry patterns in health, partial intestinal obstruction and pseudoobstruction. Gastroenterology 1983; 85: 1290-300. 